\title{
PENGARUH DONGENG TERHADAP PERUBAHAN GANGGUAN TIDUR ANAK USIA PRASEKOLAH AKIBAT HOSPITALISASI DI RUMAH SAKIT
}

\author{
Rinik Eko Kapti, Ahsan, Siti Nur Rizky Setianingrum \\ Jurusan Keperawatan Fakultas Kedokteran Universitas Brawijaya \\ Jl. Veteran malang Jawa Timur \\ email : rinik.kapti@gmail.com
}

\begin{abstract}
Sleep disorder is one of the effects in a preschool children who are undergoing hospitalization. Fulfilling sleep and rest need for children is important to support the recovery of his health status. Activities such Storytelling is one of the non-pharmacological treatment of sleep disorders that use the principles of distraction. This study aims to determine the effect of a Storytelling to the change of preschooler sleep disorders. This study uses a true experimental design with a method called as pretest posttest control group design which is conducted on 10 respondents control group and 10 respondents treatment groups by providing a storytelling activity in the treatment group. The sampling was taking by using probability sampling with a method called as simple random sampling. The results of this study show about the control group with $70 \%$ of respondents who experienced a decrease in sleep disorders but not significant and $30 \%$ of respondents did not experience a decrease in sleep disorders. In the treatment group, the results showed that $100 \%$ of respondents decreased sleep disorders. Based on the results of the analysis of the dependent $T$ test showed a significant result $(p=0.000<0.05)$ in the treatment group, but the analysis results dependent $T$ test did not show significant results $(p=0.326>0.05)$ in the control group and independent $T$ test of the difference between the results of control and treatment groups showed significant values $(p=0.002<0.05)$. The conclusion, there are significant influences of storytelling to the change of preschooler sleep disorders due to the hospitalization. The advice for this study, from now hospitals can use the method of storytelling as a way to resolve children's sleep disorders which is caused by hospitalization.
\end{abstract}

Keywords : sleep disorders, preschooler, hospitalization, storytelling

Abstrak : Gangguan tidur merupakan salah satu dampak yang sering muncul pada populasi anak usia prasekolah yang sedang menjalani hospitalisasi. Dalam keadaaan sakit, pemenuhan kebutuhan anak terkait tidur dan istirahat sangatlah penting untuk mendapatkan energi demi mendukung pemulihan status kesehatannya. Aktivitas membacakan dongeng merupakan salah satu terapi nonfarmakologis gangguan tidur yang dilakukan dengan prinsip distraksi atau pengalihan perhatian anak terhadap sakitnya dengan cara membacakan dongeng yang menyenangkan. Penelitian ini bertujuan untuk mengetahui pengaruh dongeng terhadap perubahan gangguan tidur anak usia prasekolah akibat hospitalisasi. Penelitian ini menggunakan desain true experimental dengan metodepretest posttest control group design dilakukan pada 10 responden kelompok kontrol dan 10 responden kelompok perlakuan.Pengambilan sampel menggunakan probability sampling dengan metode simple random sampling. Hasil dari penelitian ini menunjukkan pada kelompok kontrol terdapat $70 \%$ responden yang mengalami penurunan gangguan tidur namun tidak signifikan dan $30 \%$ responden tidak mengalami penurunan gangguan tidur. Pada kelompok perlakuan, hasil menunjukkan $100 \%$ responden mengalami penurunan gangguan tidur.Bedasarkan hasil analisis uji $\mathrm{T}$ dependen menunjukkan hasil signifikan $(p=0,000<0,05)$ pada kelompok perlakuan, hasil analisis uji T dependen menunjukkan hasil yang tidak signifikan $(p=0,326>0,05)$ pada kelompok kontrol dan uji $T$ independen antara selisih hasil kelompok kontrol dan perlakuan menunjukkan nilai signifikan $(p=0,002<0,05)$. Kesimpulan penelitian ini adalah terdapat pengaruh dongeng terhadap perubahan gangguan tidur anak usia prasekolah akibat hospitalisasi secara nyata. Saran yang dapat diberikan dalam penelitian ini adalah agar rumah sakit dapat menggunakan metode mendongeng sebagai salah satu upaya mengatasi gangguan tidur anak akibat hospitalisasi.

Kata kunci : gangguan tidur, anak Usia prasekolah, hospitalisasi, dongeng

\section{PENDAHULUAN}

Anak merupakan individu yang masih sangat bergantung pada orang dewasa dan lingkungannya, artinya anak membutuhkan lingkungan yang dapat memfasilitasi dalam memenuhi kebutuhan dasarnya dan untuk belajar mandiri (Supartini , 2004). Anak usia prasekolah sangat rentan terkena penyakit, sehingga 
banyak anak pada usia tersebut yang harus dirawat di rumah sakit (Wong, 2009). Hospitalisasi atau rawat inap merupakan sebuah proses yang mengharuskan seseorang anak untuk tinggal di rumah sakit karena adanya gangguan kesehatan untuk menjalani terapi dan perawatan sampai pada waktu anak telah diperbolehkan pulang (Supartini, 2004). Sedangkan, menurut Asmadi (2008) hospitalisasi merupakan sebuah pengalaman yang tidak menyenangkan dan dianggap mengancam sehingga menjadi pengalaman yang traumatik bagi setiap orang yang pernah mengalaminya.

Di Indonesia tampak dari hasil penelitian Muchlastriningsih pada tahun 2005 dalam buku Hidayat (2008) yang menunjukkan bahwa sekitar 60,28\% pasien rawat inap adalah bayi dan anakanak, sedangkan di Indonesia tahun 2008 pada penelitian yang dilakukan Sumaryoko dalam Puwandari (2010) diperkirakan sekitar 35 per 1000 anak menjalani hospitalisasi. Sedangakan di RSUD kanjuruhan pada ruang Empu Tantular pada 3 bulan terakhir tahun 2015 terdapat rata - rata sekitar 28 anak usia prasekolah yang mengalami hospitalisasi.

Salmela, dkk (2010) dalam penilitiannya tentang The experience of hospital related fears of 4 to 6 years old child menunjukkan terdapat beberapa stressor yang akan dihadapi anak ketika mengalami hospitalisasi, stressor tersebut dapat berupa proses perpisahan dengan orang tua , pertemuan dengan orang baru atau asing, lingkungan baru, nyeri, perasaan terancam akibat tubuh yang cedera, suntikan dengan jarum, kurangnya informasi, kekhawatiran menjalani operasi dan tindakan prosedur. Menurut Das Samita, dkk (2015) bahwa sebagian banyak stressor yang didapatkan tersebut dapat menyebabkan gangguan tidur pada pasien hospitalisasi. Das Sasmita (2015) dalam penelitiannya tentang factors of sleep disturbance among hospitalized patients juga menyatakan bahwa faktor lingkungan yang baru atau asing memiliki konstribusi yang cukup besar terhadap terjadinya gangguan tidur. Selain itu, nyeri juga merupakan stressor faktor internal yang turut serta membuat anak mengalami gangguan tidur saat hospitalisasi.
Nyeri dianggap sebagai faktor internal yang sangat mengganggu tidur saat hospitalisasi karena lebih dari setengah pasien yang diteliti merasa terganggu oleh hal tersebut. Gangguan tidur pada dasarnya sangatlah wajar terjadi pada pasien yang sedang mengalami hospitalisasi, termasuk anak-anak yang sedang mengalami hospitalisasi. Namun, apabila gangguan tidur tersebut tidak segera ditangani maka akan memberikan pengaruh buruk terhadap penderita. Hal tersebut dapat berdampak kurang baik terhadap perkembangan kesembuhan anak karena pada seseorang yang mengalami gangguan tidur maka dapat mempengaruhi sistem kekebalan tubuhnya.

Gangguan tidur anak pada hospitalisasi dapat diatasi dengan di berikan tindakan yang dapat meningkatkan pola dan kualitas tidur anak menjadi lebih baik. Tindakan tersebut dapat dilakukan dengan berbagai kegiatan yang membuat anak merasa senang dan nyaman, seperti contohnya terapi bermain. Ada beberapa jenis terapi bermain salah satunya adalah terapi bermain teknik bercerita. Metode bercerita atau mendongeng merupakan metode yang cukup efektif dalam menarik perhatian seseorang. Mendongeng adalah seni bercerita menggunakan bahasa, vokalisasi, gerakan fisik dan isyarat tertentu untuk mengungkapkan unsur-unsur dari cerita ke pendengar (Haven, 2000). Metode mendongeng merupakan kegiatan menyenangkan dimana anak akan mendengarkan cerita yang menarik sehingga diupayakan anak bisa merasa lebih santai dan nyaman sehingga dapat membantu anak melupakan sejenak perasaan atau emosi negatif akibat stressor yang diterima sehingga anak dapat tidur dengan lebih baik (Hedo \& Sudhana, 2014).

Berdasarkan latar belakang di atas, sehingga peneliti berkeinginan menguji apakah metode mendongeng akan dapat membantu mengatasi gangguan tidur pada anak usia prasekolah yang sedang menjalani hospitalisasi. Berdasarkan hal tersebut maka penelitian ini bertujuan untuk mengetahui pengaruh dongeng terhadap perubahan gangguan 
tidur anak usia prasekolah akibat hospitalisasi

\section{METODE PENELITIAN}

Rancangan penelitian ini adalah penelitian true experimental dengan pretest posttest control group design yang melibatkan kelompok intervensi dan kelompok kontrol. Populasi dalam penelitian ini adalah anak usia prasekolah (3 - 6 tahun) yang menjalani hospitalisasi di RS selama periode waktu pengambilan data. Sampel untuk kedua kelompok sebanyak 20 anak diambil secara probability sampling dengan teknik simple random sampling. Instrumen dalam penelitian ini adalah modifikasi dari kuesioner Children's Sleep Habit Questionnaire (CSHQ) oleh Owens et al., (2002) dengan menghapus beberapa item yang tidak sesuai untuk kondisi di ruang rawat inap. Uji validitas 33 butir pertanyaan menunjukkan hasil $r$ hitung $>0,632(r$ tabel) dan uji reliabilitas menunjukkan nilai Cronbach's Alpha 0,967.

\section{HASIL PENELITIAN}

Pada bab ini peneliti akan menguraikan hasil penelitian dan analisis data tentang pengaruh dongeng terhadap perubahan gangguan tidur anak usia prasekolah akibat hospitalisasi di RS. Berdasarkan data usia dapat diketahui bahwa responden yang mengalami hospitalisasi pada kelompok kontrol terbanyak pada usia 3 tahun dan 5 tahun dengan jumlah masing - masing sebanyak 3 orang. Usia 4 dan 6 tahun masingmasing 2 orang. Sedangkan pada kelompok perlakuan responden terbanyak pada usia 3 tahun dan 6 tahun dengan jumlah masing - masing sebanyak 3 orang. Usia 4 dan 5 tahun masing-masing 2 orang.

Berdasarkan jenis kelamin didapatkan hasil bahwa dari kelompok kontrol, responden yang berjenis kelamin perempuan sebanyak 7 orang dan responden yang berjenis kelamin laki-laki sebanayk 3 anak. Sedangkan pada kelompok perlakuan memliki perbandingan yang sama antara perempuan dan lakilaki. Masing-masing berjumlah 5 anak. Sehingga, dari 20 responden yang diteliti sebagian besar berjenis kelamin perempuan sebanyak 12 responden $(60 \%)$ dan berjenis kelamin laki-laki sebanyak 8 responden (40\%).

Berdasarkan pengalaman dirawat didapatkan bahwa responden kelompok kontrol yang pernah mengalami rawat inap sebanyak 4 orang dan 6 orang responden mengatakan belum pernah memngalami rawat inap. Sedangkan pada kelompok perlakuan, memliki perbandingan yang sama antara yang pernah mengalami rawat inap dan yang belum mengalami rawat inap yaitu masingmasing berjumlah 5 orang. Sehingga, dari 20 responden yang diteliti sebagian besar pernah dirawat di rumah sakit sebelumnya sebesar $45 \%$ dan yang baru pertama kali dirawat di rumah sakit sebanyak $55 \%$

\section{Data Khusus Penelitian}

Perbedaan gangguan tidur pada pre dan post test sesuai rata-rata skor pada kelompok kontrol dan kelompok intervensi yang diuji T dependen.

Tabel 1. Perbedaan gangguan tidur pada pre dan post test kelompok kontrol

\begin{tabular}{ccccc}
\hline Variabel & N & Mean & SD & P-Value \\
\hline Pretest & 10 & 63,10 & 9,19 & 0.326 \\
Posttest & 10 & 59.30 & 4,69 & 0.326 \\
\hline
\end{tabular}

Tabel 2. Perbedaan gangguan tidur pada pre dan post test kelompok perlakuan

\begin{tabular}{ccccc}
\hline Variabel & N & Mean & SD & P-Value \\
\hline Pretest & 10 & 64,5 & 7,64 & 0,000 \\
Posttest & 10 & 43,6 & 6,50 & 0,000 \\
\hline
\end{tabular}

Analisis uji $\mathrm{T}$ dependen dengan tingkat kepercayaan 95\% ( $p \leq 0,05)$ pada kelompok kontrol menunjukkan hasil yang tidak signifikan $(p=0,326)$. Sedangkan 
kelompok perlakuan diperoleh nilai $p$ value 0,000 ( $p$ Value < $\alpha$ ), maka $\mathrm{H}_{0}$ ditolak, yang berarti gangguan tidur responden kelompok intervensi saat pre dan post test adalah tidak sama/berbeda secara nyata. Perbedaan gangguan tidur pada pre dan post test sesuai selisih hasil skor pre test dan post test antara kelompok kontrol dengan intervensi yang diuji $\mathrm{T}$ independen.

Tabel 3. Hasil Analisis Uji Unpaired Sampel T-Test

\begin{tabular}{ccccc}
\hline Variabel & $\mathrm{N}$ & Mean & SD & P- Value \\
\hline Kontrol & 10 & $-3,80$ & 11,57 & 0,002 \\
Perlakuan & 10 & $-20,9$ & 9,58 & \\
\hline
\end{tabular}

Analisis uji $\mathrm{T}$ independen skor gangguan tidur selisih skor pre-post antara kelompok kontrol dengan intervensi didapatkan nilai $p$-value $(p=0,002)<0,05$ menunjukkan $\mathrm{H}_{0}$ ditolak yang artinya intervensi terapi membacakan dongeng memiliki pengaruh terhadap gangguan tidur pada anak usia prasekolah yang menjalani hospitalisasi.

\section{PEMBAHASAN}

Gangguan tidur anak sebelum dan sesudah pada kelompok kontrol

Pada kelompok kontrol telah diketahui bahwa nilai rata - rata pre test pada pengukuran skor gangguan tidur anak sebesar 63,10 dengan standart deviasi (SD) 9,19. Sedangkan pada nilai post test didapatkan skor rata- rata 59,30 dengan standart deviasi (SD) 4,69. Dari data tersebut dapat dianalisis bahwa pada hasil pengukuran mean dan standart deviasi tidak memiliki rentan yang sangat jauh di bandingkan dengan kelompok perlakuan. Hal tersebut sejalan dengan Teori yang diungkapkan Roy dalam buku Nursalam (2005) yang mengatakan kemampuan adaptasi individu bergantung dari stimulus yang didapat bedasarkan kemampuan individu. Tingkat respon individu sangat unik dan bervariasi bergantung pada pengalaman yang didapatkan sebelumnya, status kesehatan individu, dan stressor yang diterima. Sebagai sistem adaptasi, tingkat adaptasi seseorang dipengaruhi oleh perkembangan individu dan penggunaan mekanisme koping. Wong (2009) mengatakan bahwa anak-anak cenderung memiliki mekanisme koping yang terbatas.
Wahyuningsih \& Febriani (2011) dalam penelitiannya menjelaskan banyaknya stimulus dapat menimbulkan gejala psikologis seperti kecemasan yang membuat respon hipotalamus meningkat sehingga individu akan sulit tertidur dan cenderung terjaga. Apabila stress tersebut tidak dapat di tangani ditambah dengan kemampuan coping yang terbatas serta tidak diberikannya tindakan untuk mengatasi gangguan tidur maka hal tersebut akan menyebabkan anak untuk sulit beradaptasi dengan lingkungannya sehingga menyebabkan anak akan tetap mengalami gangguan tidur.

Nilai pre test dan post test pada penelitian ini dengan mean pretest 63,10 dan post test 59,30 dengan $p$ value $0,326>0,05$ menunjukkan tidak terjadi perubahan yang signifikan tersebut juga sesuai dengan penelitian yang dilakukan oleh Putri (2014), yang melakukan penelitian tentang pengaruh sleep hygiene terhadap gangguan tidur anak usia sekolah yang menjalani hospitalisasi. Hasil penelitian tersebut pada kelompok kontrol mean antara pre test dan post test juga tidak mengalami peningkatan yang signifikan atau dapat dikatakan hampir sama yaitu pre test 72,57 dan post test 70,3 dengan $p$ Value $0,290>0,05$. Dengan demikian, dapat dikatakan bahwa pada kelompok kontrol perubahan atau penurunan skor gangguan tidur tidak terjadi perubahan yang signifikan.

Gangguan tidur Anak Sebelum dan Sesudah Diberikan Intervensi pada Kelompok Perlakuan 
Pada kelompok perlakuan telah diketahui bahwa nilai rata-rata pretest pada pengukuran skor gangguan tidur anak sebesar 64,50 dengan standart deviasi (SD) 7,64. Sedangkan pada nilai posttest pengukurang gangguan tidur anak yang dibacakan dongeng didapatkan skor rata-rata 43,60 dengan standart deviasi (SD) 6,50. Hasil uji statistik Paired $t$ test yang menunjukkan signifikansi $0,000<\alpha$ dengan tingkat kepercayaan $95 \%$ yang artinya terdapat perbedaan yang signifikan pada nilai pre test dan post test setelah diberikan intervensi pembacaan dongeng pada anak usia prasekolah yang mengalami Hospitalisasi.

Hasil Penelitian ini menununjukkan bahwa $100 \%$ responden mengalami penurunan skor gangguan tidur. Terjadinya perubahan yang signifikan tersebut juga sejalan dengan penelitian yang dilakukan Anggraeni (2014) pada penelitiannya pengaruh terapi music pada kualitas tidur anak. Anggraeni menyebutkan bahwa hasil dari penelitiannya terdapat $68,8 \%$ responden memiliki kualitas tidur yang baik setelah diberikan intervensi dengan hasi uji $p$ value $<0,05$. Menurut Merry dalam Anggreani (2014) rileksasi sebelum tidur dapat meningkatkan kualitas sebelum tidur. Pemberian ritual pra tidur sekitar 10 menit hingga satu jam dapat meringankan stress. Pemberian ritual pra tidur tersebut dapat berupa relaksasi dengan bacaan ringan, meditasi, terapi aroma, peregangan cahaya, mandi air hangat atau dengan mendengarkan musik.

Hasil penelitian ini juga sesuai dengan penelitian yang dilakukan Soares VA, Silva Da, dan Santos PM ( 2016) bahwa membacakan dongeng menjadi salah metode bermain yang menyenangkan. Melalui bermain anak - anak memiliki kemampuan dan menemukan kembali dunia mereka. Pembacaan dongeng dapat menjadi media yang menyenangkan untuk mengalihkan perhatian dan mengurangi kegelisahan sehingga anak akan lebih mudah beradaptasi dan merasa lebih nyaman berada di lingkungan rumah sakit. Perasaan nyaman dan relaks tersebut dapat membuat anak melupakan kecemasaanya sehingga anak dapat tidur dengan perasaan tenang
Hasil penelitian ini juga didukung oleh penelitian yang dilakukan oleh Hedo dan Sudhana (2014) yang menyatakan bahwa dengan membacakan dongeng sebelum tidur dapat menurunkan agresivitas anak secara signifikan yang dibuktikan dengan hasil $p$ sebesar 0,000 atau $p<$ 0,05 . Hasil tersebut juga sesuai dengan yang dikemukakan Katinawati (2012) bahwa cerita dongeng dapat bermanfaat sebagai obat untuk menyembuhkan sakit karena cerita membawa pada suasanan yang menyenangkan. Cerita akan menumbuhkan spirit, sugesti, dan juga sedikit hipnotis sehingga akan mendorong anak yang sedang mengalami perawatan di rumah sakit untuk cepat sembuh. Dengan demikian dapat dikatakan bahwa dongeng dapat berpengaruh pada penurunan gangguan tidur secara signifikan.

\section{Analisis Pengaruh Dongeng Terhadap Penurunan gangguan tidur anak pada Kelompok Perlakuan dan Kelompok Kontrol}

Berdasarkan hasil uji Statistik independent $t$ test dapat diketahui bahwa nilai $P<\alpha(0,000<0,05)$, yang menunjukkan bahwa $\mathrm{HO}$ di tolak. Hal ini menunjukkan bahwa terdapat perbedaan hasil antara kelompok kontrol dan kelompok perlakuan. Dengan demikian dapat dikatakan hasil kelompok perlakuan lebih baik dibandingkan dengan hasil kelompok kontrol responden anak pada kelompok kontrol dan intervensi menerima stresor yang sama saat dirawat dan menjalani hospitalisasi, dimana pada kondisi tersebut anak akan berusaha mengembangkan perilaku atau strategi dalam menghadapi stresor tersebut sehingga akan mampu beradaptasi dengan lingkungannya. Pemberian pembacaan dongeng menjadi sebuah kegiatan yang dilakukan pada anak kelompok intervensi sebagai salah satu cara untuk mengatasi masalah gangguan tidurnya. Hal inilah yang menyebabkan perbedaan gangguan tidur kedua kelompok dimana kedua kelompok mengalami penurunan skor post test, namun kelompok intervensi skornya turun lebih banyak sehingga terlihat efek pembacaan dongeng terhadap gangguan tidur anak. 
Selain itu, adanya perbedaan nilai yang signifikan antara kelompok kontrol dan kelompok perlakuan tersebut dapat didukung dengan teori yang diungkapkan Potter dan Perry (2005) bahwa cerita diberikan sebagai pereda ketegangan. Bercerita akan merangsang batang otak atas dalam mengaktivasi korteks serebral. Aktivasi korteks serebral kemudian akan menstimulasi penurunan Reticular Activating System (RAS). Dimana RAS diyakini mengandung sel-sel khusus yang memiliki peran dalam mempertahan-kan keadaan terjaga dan siaga. Sehingga dengan terjadinya penurunan stimulus pada RAS akan membuat aktivasi RAS akan semakin menurun pula. Kondisi inilah yang akan membuat tubuh melepaskan serotonin dari sel Bulbar Synchronizing Region (BSR) yang akan menimbulkan rasa tenang bagi tubuh. Timbulnya rasa tenang dari tubuh tersebut akan dapat menghilangkan rasa cemas yang dirasakan anak akibat dampak hospitalisasi. Dimana rasa cemas tersebut merupakan salah satu bentuk stress psikologis yang dapat menjadi penyebab gangguan tidur pada anak (Wahyuningsih \& Febriani , 2011).

Penurunan skor gangguan tidur pada post test kelompok intervensi yang cukup besar membuktikan bahwa pembacaan dongeng dapat menurunkan gangguan tidur anak menjadi lebih baik dengan memberikan suasana yang menyenangkan dan relaks sebagai bentuk distraksi dari kecemasan yang dialaminya.

Pada kelompok kontrol juga terdapat penurunan skor gangguan tidur walaupun nilainya kecil hal tersebut mungkin dapat berkaitan dengan

\section{DAFTAR PUSTAKA}

Anggraeny, et al. Pengaruh Terapi Musik Pop Terhadap Kualitas Tidur Anak Usia Sekolah (6-12 Tahun) yang Dirawat di RSUD Ambarawa. Jurnal IImu Keperawatan dan Kebidanan, 2014, 1(1) : 3-6

Asmadi, 2008.Teknik Prosedur Keperawatan : Konsep dan Aplikasi Kebutuhan Dasar Klien, Salemba Medika, Jakarta kemampuan adaptasi anak. Teori menyebutkan bahwa pada dasarnya setiap orang memiliki kemampuan adaptasi dan adaptasi ini memerlukan waktu yang sangat tergantung pada kondisi anak untuk dapat menyesuaikan diri dengan situasi baru (Solikhah,2011). Berdasarkan uraian di atas dan didukung teori-teori yang sesuai dapat dikatakan bahwa pembacaan dongeng dapat menurunkan gangguan tidur anak usia prasekolah yang mengalami Hospitalisasi.

\section{KESIMPULAN}

Bedasarkan hasil penelitian diatas menunjukkan bahwa membacakan dongeng pada anak usia prasekolah sebelum tidur yang menjalani hospitalisasi dapat membantu mengurangi gangguan tidur yang timbul akibat hospitalisasi. Hal tersebut sesuai dengan hasil uji $T$ independen dengan hasil $(p=0,002<0,05)$ menunjukkan hasil yang signifikan sehingga dapat disimpulkan bahwa ada pengaruh pembacaan dongengterhadap perubahan gangguan tidur anak usia prasekolah akibat hospitalisasi di RS.

\section{SARAN}

Institusi rumah sakit diharapkan dapat mempertimbangkan penerapan pembacaan dongeng oleh perawat ruangan selama anak menjalani hospitalisasi sebagai upaya mengurangi terjadinya gangguan tidur anak akibat hospitalisasi dan mempertahankan pola tidur anak sesuai kebiasaan di rumah.

Das, S, et al.Factors of sleep disturbance among hospitalized patients, Jeopardizing the prognosis, Bhubaneswar Asian J Nursing Edu and Research, 2015, 5(2):137-139

Hedo, DJP \& Sudhana, H. Perbedaan Agresivitas pada Anak Usia Dini yang Dibacakan Dongeng dengan yang Tidak Dibacakan Dongeng Sebelum Tidur Oleh Ibu, Universitas Udayana, 2014, 1(2) :213 - 226 
Heven, KF. 2000. Super Simple Story telling : a can do guide for every classroom every day, Teacher Idea Press, East Belleview Avenue

Hidayat, AA. 2008. Pengantar IImu Kesehatan Anak untuk Pendidikan Kebidanan, Salemba Medika, Jakarta, p. 57

Katinawati. Pengaruh Terapi Bermain Dalam Menurunkan Kecemasan Pada Anak Usia Prasekolah (3-5 Tahun) yang Mengalami Hospitalisasi di Rumah Sakit Umum Daerah Tugurejo Semarang. STIKES Telogorejo Pers, 2012, 1 (2):5

Nursalam, 2008. Konsep dan Metode Keperawatan, Salemba Medika, Jakarta

Potter \& Perry. 2005. Buku Ajar Fundamental Keperawatan, Edisi Keempat, Penerbit EGC, Jakarta

Purwandari, H. 2009. Pengaruh Terapi Seni Untuk Menurunkan Tingkat Kecemasan Anak Usia Sekolah yang Menjalani Hospitalisasi di Wilayah Kabupaten Banyumas. Tesis. Tidak diterbitkan, Fakultas IImu Keperawatan Program Magister Keperawatan Universitas Indonesia, Depok.
Putri, S. 2014. Pengaruh Terapi Sleep Hygiene Terhadap Gangguan Tidur Pada Anak Usia Sekolah Yang Menjalani Hospitalisasi. Tugas Akhir. Tidak diterbitkan, Program Studi IImu Keperawatan Universitas Brawijaya, Malang.

Salmela, et al.The Experience of hospital related fears of 4 to 6 years old child. Journal child : Care, health and Development, Finland Blackwell Publishing, 2010.5 (2) : 719-726.

Solikhah,U. Therapeutic peer play sebagai upaya menurunkan kecemasan anak usia sekolah selama hospitalisasi. Jurnal Keperawatan Soedirman, 2011, 6(1) : 20-30

Supartini, Y. 2004. Buku Ajar Konsep Dasar Keperawatan Anak, Buku Kedokteran EGC, Jakarta

Wahyuningsih, A \& Febriana, D. Kajian stres hospitalisasi terhadap pemenuhan pola tidur anak usia prasekolah di ruang anak RS Baptis Kediri. Jurnal Stikes Baptis, 2011, 4(2): 66 - 70

Wong, DL, dkk. 2009. Buku Ajar Keperawatan Pediatrik. Edisi 2, Penerbit Buku Kedokteran EGC, Jakarta 